\title{
Strategi Diplomasi Kemanusiaan Pemerintah Indonesia Dalam Kasus Krisis Kemanusiaan Yang Dialami Etnis Rohingya Di Myanmar Tahun 2017
}

\author{
Ardli Johan Kusuma \\ Fakultas Ilmu Sosial dan Ilmu Politik, Universitas 17 Agustus 1945 Jakarta \\ Email: ardli.johan@yahoo.com \\ Fernando Ersento Maraden Sitorus \\ Fakultas Ilmu Sosial dan Ilmu Politik, Universitas 17 Agustus 1945 Jakarta
}

\begin{abstract}
This research wants to look at the humanitarian diplomacy strategy by the Indonesian government to provide humanitarian assistance to the Rohingya ethnic groups (especially those still in Myanmar in 2017). Myanmar's military and also the majority of people in Rakhine who are Buddhists have committed acts of violence and seized the human rights of the Rohingya ethnic group which is an ethnic minority in Rakhine who are Muslim. The issue attracted the attention of the international community, including Indonesia. This study uses a qualitative method, with a descriptive analytic approach, where data are collected by literature study. The findings of this study are: the Indonesian government has used several humanitarian diplomacy strategies, including: conducting a diplomatic approach between the Indonesian government and the Myanmar government (with due regard to the ASEAN Way), collaborating with the United Nations (offering formula $4+1$ as a form of implementation of the recommendations from Advisory Commission Report for Rakhine), involved civilians to channel aid to the Rohingya ethnic group in Myanmar (forming AKIM consisting of 11 humanitarian agencies). The strategy succeeded in breaking through the blockade carried out by the Myanmar government as an effort to block humanitarian assistance provided by the international community.
\end{abstract}

Keywords: Rohingya, Human Rights, Humanitarian Crisis, Humanitarian Diplomacy. 


\begin{abstract}
Abstrak
Penelitian ini ingin melihat terkait strategi diplomasi kemanusiaan yang dilakukan oleh pemerintah Indonesia dalam upaya memberikan bantuan kemanusiaan kepada etnis Rohingya (terutama yang masih berada di Myanmar pada tahun 2017). Militer Myanmar dan juga mayoritas masyarakat di Rakhine yang beragama Budha telah melakukan tindakantindakan kekerasan dan merampas HAM yang dimiliki etnis Rohingya yang merupakan etnis minorita di Rakhine yang beragama Islam. Isu tersebut menarik perhatian dunia internasional, termasuk Indonesia. Penelitian ini menggunakan metode kualitatif, dengan pendekatan deskriptif analitik, dimana data-data yang dikumpulkan dengan studi pustaka. Adapun temuan dari penelitian ini adalah: pemerintah Indonesia telah menggunakan beberapa strategi diplomasi kemanusiaan, diantaranya: melakukan pendekatan diplomasi antar pemerintah Indonesia dengan pemerintah Myanmar (dengan tetap memperhatikan ASEAN Way), berkolaborasi dengan PBB (menawarkan formula 4+1 sebagai bentuk implementasi dari rekomendasi Laporan Komisi Penasehat untuk Rakhine), melibatkan pihak sipil untuk menyalurkan bantuan kepada etnis Rohingya di Myanmar (membentuk AKIM yang terdiri dari 11 lembaga kemanusiaan). Strategi tersebut berhasil menembus blokade yang dilakukan oleh pemerintah Myanmar sebagai upaya untuk menghalangi bantuan kemanusiaan yang diberikan oleh komunitas internasional.
\end{abstract}

Kata kunci: Rohingya, HAM, Krisis Kemanusiaan, Diplomasi Kemanusiaan. 


\section{Pendahuluan}

Sejak Myanmar menjadi negara merdeka pada tahun 1948, etnis Rohingya yang merupakan masyarakat muslim yang minoritas telah mengalami tindakantindakan yang diskriminatif. Beberapa literatur menyebutkan bahwa "Rohingya" berasal dari kata "Rohang", yaitu sebutan dari "Arakan" di masa lalu (yang sekarang menjadi Rakhine). Dan orang-orang yang menempati wilayah itu disebut "Rohingya". Pelanggaran HAM yang dialami oleh etnis Rohingya di Myanmar terus terjadi secara berulang-ulang. Pelanggaran HAM tersebut menjadi isu krisis kemanusiaan di dunia internasional. Etnis Rohingya dianggap bukan bagian dari warga negara Myanmar, hal ini terjadi sejak diterapkannya UU kewarganegaraan di Myanmar pada thun 1982, yang menyatakan bahwa etnis Rohingya sebagai warga asing (Stateless).

Kondisi tersebut terus berlanjut hingga pada masa kepemimpinan Presiden Thein Sein yang berkuasa sejak 2011. Thein Sein bahkan cenderung meneruskan kebijakan terkait penolakan atas status kewarganegaraan etnis Rohingya di Myanmar. Etnis Rohingya dianggap sebagai illegal Bengali (salah satu etnis Bangladesh yang masuk ke wilayah Myanmar secara illegal). Penolakan status kewarganegaraan terhadap etnis Rohingya sebagai bagian dari Myanmar tercermin dalam pernyataan Sein bahwa: "Rohingya are not our people and we have no duty to protect them". Sein menginginkan agar etnis Rohingya berada dalam pengelolaan Komisi Tinggi PBB untuk Pengungsi (UNHCR) atau ditampung oleh negara ketiga (Yudyachandra, 2015).

Kebijakan ini tentunya berdampak negatif bagi etnis Rohinya di Myanmar. Dari laporan yang dirilis oleh Pusat Advokasi Hukum dan Hak Asasi Manusia Indonesia (PAHAM INDONESIA) disebutkan bahwa beberapa tindakan diskriminasi yang dialami etnis Rohingya diantaranya: pembatasan lapangan pekerjaan, penyitaan properti, kerja paksa, pembunuhan, pemerkosaan terhadap wanita Rohingya, dan maraknya pembakaran rumah dan tempat ibadah para etnis Rohinya (PAHAM INDONESIA, 2012).

Sering muncul konflik yang kemudian menempatkan etnis Rohingya sebagai korban sasaran bagi masyarakat mayoritas di Myanmar. Dari konflikkonflik yang terjadi dan menimbulkan banyak korban jiwa dari etnis Rohinya berdampak pada timbulnya gelombang pengungsian untuk mencari suaka ke negara-negara lain yang berdekatan dengan Myanmar. Masyarakat etnis 
Rohingnya memilih untuk mengungsi untuk menyelamatkan diri dari operasi militer yang dilakukan oleh pemerintah Myanmar. Sebagai contoh adalah terjadinya gelombang pengungsian pada tahun 2017. Hanya dalam waktu satu bulan, jumlah pengungsi etnis Rohingnya dari bulan Agustus hingga September mencapai 123.000 orang (BBC Indonesia, 2017).

Krisis kemanusiaan yang dialami etnis Rohinya, mendapatkan perhatian dari dunia komunitas internasional, termasuk Indonesia. Bagi pemerintah Indonesia, kasus kemanusiaan yang dialami etnis Rohinya merupakan masalah yang penting untuk diselesaikan, terlebih lagi, Indonesia menjadi salah satu negara yang dijadikan tujuan bagi etnis Rohinga untuk menyelamatkan diri dari Myanmar. Dengan demikian disamping nilai kemanusiaan, Indonesia juga memiliki kepentingan untuk aktif mencari solusi masalah krisis kemanusiaan tersebut, karena Indonesia terkena dampak secara langsung dari kasus krisis kemanusiaan itu (Moy \& Kusuma, 2016). Untuk masyarakat etnis Rohingya yang masih bertahan di negara bagian Rakhine Myanmar, mereka tidak diberikan akses, karena wilayah tersebut ditutup dan dijaga ketat oleh militer Myanmar, sehingga menyebabkan bantuan kemanusiaan sulit untuk menjangkau mereka (Bonasir, 2017). Indonesia yang sejak awal berkomitmen untuk ikut aktif dalam mencari solusi atas krisis kemanusiaan yang dialami etnis Rohingya berupaya untuk melakukan diplomasi kemanusiaan, dengan tujuan masalah krisis kemanusiaan tersebut dapat diselesaikan dengan baik. Bahkan Menteri Luar Negeri RI yaitu Retno Lestari Priansari Marsudi menyatakan bahwa Indonesia adalah negara pertama di dunia yang bersedia ikut ambil peran dalam upaya menyelesaikan kasus krisis kemanusiaan yang terjadi di Rakine, Myanmar, yang sempat memanas pada Oktober 2016 (Nadlir, 2017).

\section{Kerangka Konseptual (Diplomasi}

\section{Kemanusiaan)}

Diplomasi kemanusiaan harus dilihat secara berbeda dengan proses diplomasi yang lain. Jika diplomasi pada umumnya dilihat sebagai suatu upaya pencapaian kepentingan, maka berbeda dengan diplomasi kemanusiaan, sebagaimana yang dijelaskan oleh Larry

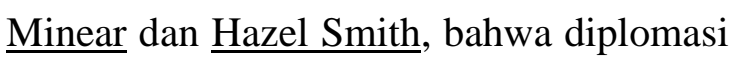
kemanusiaan dapat dilihat sebagai upayaupaya yang dilakukan untuk mendapatkan akses terhadap masyarakat yang sedang mengalami krisis. Lebih lanjut Larry

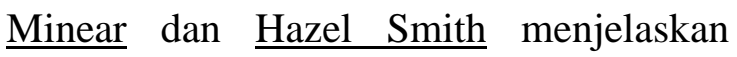
bahwa diplomasi kemanusiaan umumnya 
dilakukan dengan cara-cara yang tidak biasa dan dapat dikembangkan sesuai dengan situasi dan kondisi, serta melibatkan banyak pihak, Karena diplomasi kemanusiaan biasanya bersifat ad hoc, dalam hal ini sangat bersifat kondisional karena tergatung dari masalah krisis kemanusiaan yang terjadi dalam kurun waktu tertentu dan dalam konteks wilayah tertentu (Minear \& Smith, 2007). Diplomasi kemanusiaan berlandaskan kepentingan nilai atau norma terkait kemanusiaan, yang harus dimaknai secara berbeda dengan konsep diplomasi yang lain seperti diplomasi keamanan, diplomasi ekonomi, atau diplomasi kekuasaan, yang pada umumnya jika ditinjau dari tujuannya, diplomasidiplomasi tersebut didasari pada kepentingan-kepentingan yang bersifat materialisme (Roy, 1991).

\section{Diplomasi kemanusiaan yang} dilakukan pemerintah Indonesia dalam kasus krisis kemanusiaan yang dialami etnis Rohingya di Myanmar, menunjukkan komitmen dari pemerintah Indonesia untuk berupaya mencari jalan keluar atas kasus krisis kemanusiaan yang dialami etnis Rohingya tersebut. Menteri Luar Negeri RI yaitu Retno Lestari Priansari Marsudi, dalam sebuah forum ilmiah telah menjeaskan bahwa Indonesia telah menonjolkan dua tipe diplomasi yang dilakukan dalam dunia internasional. Indonesia sedang gencar mengedepankan diplomasi perdamaian dan diplomasi kemanusiaan. Lebih lanjut dia menjelaskan bahwa dua diplomasi tersebut saling berkaitan erat dan tujuan finalnya adalah untuk memperjuangkan nilai kemanusiaan (A. Maulana, 2018).

$$
\text { Bagi pemerintah Indonesia, }
$$
mengedepankan diplomasi perdamaian dan diplomasi kemanusiaan menjadi satu hal yang memang harus dilakukan. Terwujudnya nilai-nilai perdamaian dan kemanusiaan didunia menjadi bagian dari cita-cita bangsa Indonesia, sebagaimana tertuang dalam pembukaan UUD 1945 dalam alinea 4 yang berbunyi “...ikut melaksanakan ketertiban dunia yang berdasarkan kemerdekaan, perdamaian abadi dan keadilan sosial...". Untuk itu pemerintah Indonesia aktif berupaya dapat menjangkau masyarakat Rohingya yang sedang mengalami krisis kemanusiaan dan dirampas hak-hak mereka, serta mencari jalan terbaik untuk menghentikan pelanggaran HAM yang terjadi dengan melakukan berbagai strategi dalam kerangka diplomasi kemanusiaan. 


\section{Pembahasan}

\section{a. Situasi Krisis Kemanusiaan} Yang Dialami Etnis Rohingya

Etnis minoritas Rohingnya sudah tinggal di Myanmar selama berabad-abad. Namun pemerintah Myanmar menganggap bahwa Rohingya bukan kelompok etnis asli. Keturunan Rohingya dianggap sebagai pengungsi ilegal etnis Bengali dari negara Banglades. Di pihak lain, Banglades juga tidak mengakui mereka sebagai warga negara. Saat ini terdapat sekitar 300.000 warga Rohingya di Banglades, terutama di kawasan perbatasan di Myanmar. Dengan kata lain status etnis Rohingnya saat ini bisa dikatakan tanpa kewarganegaraan dan tanpa perlindungan nasional dari negara manapun. Hal tersebut tentu saja melanggar hak asasi manusia dari etnis Rohingnya. Terutama jika kita kaitkan dengan konsep "International Bill of Human Rights", khususnya (Universal Declaration of Human Rights) dalam pasal 13, 14 dan 15 yang menjelaskan tentang hak seseorang untuk mendapatkan status kewarganegaraan dan perlindungan dari penindasan. Dimana pasal 13 ayat 1 dan 2 yang berbunyi :

(1) Everyone has the right to freedom of movement and residence within the borders of each state. (2) Everyone has the right to leave any country, including his own, and to return to his country.

Kemudian pasal 14 ayat 1 dan 2 yang berbunyi :

(1) Everyone has the right to seek and to enjoy in other countries asylum from persecution. (2) This right may not be invoked in the case of prosecutions genuinely arising from nonpolitical crimes or from acts contrary to the purposes and principles of the United Nations.

Dan berikutnya adalah pasal 15 ayat 1 dan 2 yang berbunyi :

(1) Everyone has the right to a nationality. (2) No one shall be arbitrarily deprived of his nationality nor denied the right to change his nationality (United Nations, 1948).

Jika kita membaca pasal tersebut sudah sangat jelas bahwa hak etnis Rohingnya untuk mendapatkan kejelasan status kewarganegaraan telah direnggut. Padahal mereka sudah menempati negara Myanmar selama berabad-abad.

Sejak berdirinya negara Myanmar tahun 1948, etnis Rohingya yang merupakan minoritas, banyak mengalami diskriminasi dan tindakan pelanggaran HAM. Kemudian pada tahun 1962, saat Jenderal $\mathrm{Ne}$ Win berhasil melakukan kudeta dan mengambil alih kekuasaan atas pemerintahan Myanmar, rezim ini 
langsung melakukan operasi militer untuk meredam aksi separatis dari etnis Rohingya. Salah satu operasi militer yang dilancarkan pada tahun 1978 dikenal dengan sebutan "Operasi Raja Naga" atau (Dragon King Operation / Naga Min) yang menyebabkan lebih dari 200.000 orang Rohingya melarikan diri dan mengungsi ke Bangladesh akibat kekerasan, pembunuhan dan pemerkosaan besar-besaran. Pemerintah Bangladesh menyatakan protes terhadap Myanmar atas masuknya gelombang pengungsi etnis Rohingya ke wilayah negaranya. Pada bulan Juli 1978 setelah dimediasi oleh PBB, pemerintah Myanmar menyetujui untuk menerima para imigran Rohingya untuk kembali ke Rakhine dan sejak saat itu, berdasarkan keterangan dari Amnesty Internasional telah terjadi berbagai tindakan diskriminatif dan penindasan hak asasi manusia yang dilakukan oleh Junta Militer Myanmar (Mitzy, 2014).

Menurut Burmese Rohingya Organisation UK (Brouk) atau organisasi Rohingya di Inggris, Pemerintah Myanmar selalu membuat kebijakan yang menekan kelompok etnis Rohingya sejak 1970-an. Tekanan terhadap warga Rohingya secara bertahap meningkat sejak proses reformasi yang diperkenalkan Presiden Thein Sein pada 2011 (Purwanto, 2015). Kemudian pada Juni dan Oktober 2012, meletus konflik di wilayah Rakhine atau Arakan yang menjadikan kelompok Rohingya sebagai sasaran kekerasan. Jika ditelusuri lebih jauh, konflik yang meletus pada 2012 yang terus berlanjut itu bukan sesuatu yang berdiri sendiri. Menilik sejarahnya, krisis Rohingya tidak bisa dilepaskan dari persoalan diskriminasi yang dilakukan oleh pemerintah Myanmar.

Kemudian konflik ini berlanjut. Dan pada bulan juli 3013, hanya dalam tempo waktu satu bulan, tercatat 650 orang etnis Rohingya tewas, 1.200 warga hilang, dan sekitar 80 ribu lainnya kehilangan tempat tinggal. Selama bertahun-tahun pemerintah junta militer Myanmar tidak hanya melakukan pengingkaran terhadap demokrasi, tapi juga melanggar hak asasi manusia (HAM) kaum minoritas (Mangku, 2013b).

Pada pertengahan tahun 2015, tepatnya pada bulan mei, muncul gelombang pengungsian yang dilakukan oleh masyarakat etnis Rohingnya yang kemudian memasuki wilayah Indonesia, Malaysia, dan Thailand. Para pengungsi dari Myanmar ini sebenarnya tidak bertujuan untuk mendatangi ketiga negara tersebut. Namun pengungsi dari kelompok etnis minoritas di Myanmar itu menargetkan Australia sebagai negara tujuan untuk memperoleh suaka. Mereka berharap di Negara Kanguru itu dapat 
menjalani kehidupan yang lebih baik (Tempo.co, 2015). Harapan para pengungsi Rohingya tidak dapat terpenuhi, karena pemerintah Australia menolak dan membelokkan kapal imigran ilegal pencari suaka kembali ke tengah laut. Padahal Australia merupakan negara yang turut meratifikasi Konvensi mengenai Status Pengungsi yang Disetujui pada tanggal 28 Juli 1951, tentang Status Pengungsi dan Orang-orang Tidak Berkewarganegaraan. Untuk itu seharusnya Australia memberikan bantuan dan mengizinkan para pengungsi masuk kedalam wilayah Australia. Namun ternyata meskipun negara kanguru menjadi negara yang meratifikasi konvensi tersebut tetap saja Australia tidak mengizinkan pengungsi yang dianggap ilegal untuk tidak bisa masuk wilayahnya. Sehingga para pengungsi dari Rohingnya terombang-ambing di lautan dan terpaksa memasuki wilayah negara Indonesia, Malaysia dan Thailand.

Kekerasan yang dialami oleh etnis Rohingnya di Myanmar terus berlanjut. Pada tahun 2017 kekerasan yang terjadi menimbulkan banyak korban. Hanya dalam waktu satu minggu telah menewaskan kurang lebih 400 orang (Muhaimin, 2017). Hanya dalam waktu satu bulan, jumlah pengungsi etnis Rohingnya dari bulan Agustus hingga
September, mencapai 123.000 orang (BBC Indonesia, 2017). PBB menyebutkan bahwa etnis Rohingnya di Myanmar merupakan kaum minoritas di dunia yang paling teraniaya (Mangku, 2013a). Bahkan jumlah pengungsi dari negara Myanmar, pada tahun 2017 mengalami kenaikan angka yang signifikan jika dibandingkan dengan tahun-tahun sebelumnya. Data yang dirilis oleh Our World in Data, yang mengacu pada data dari World Bank, pada tahun 2017, jumlah pengungsi yang berasal dari Myanmar mencapai 1.156.732 orang (Our world in Data, 2017). Adapun perkembangan jumlah pengungsi dari Myanmar, sejak tahun 1990 hingga 2017 dapat dilihat pada gambar diagram berikut ini:

\section{Gambar 1. Populasi pengungsi berdasarkan negara atau wilayah asal (Myanmar)}

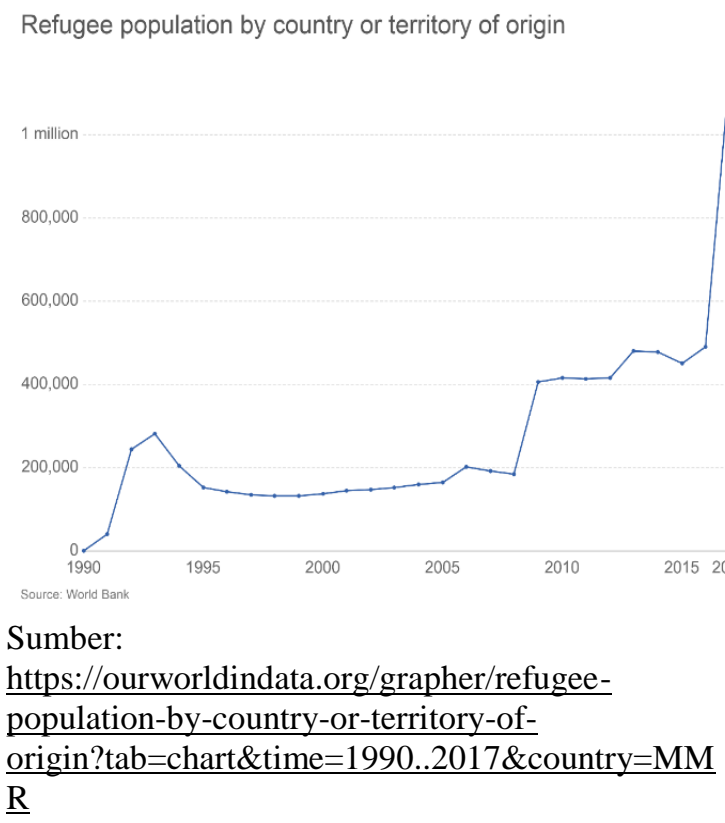


Segala bentuk diskriminasi dan kekerasan yang dialami oleh etnis Rohingnya di Myanmar sudah lebih dari cukup untuk menunjukkan adanya pelanggaran terhadap hak-hak yang seharusnya dimiliki oleh orang-orang etnis Rohingnya. karna sebenarnya hak dasar tersebut sudah jelas tercantum dalam (Universal Declaration of Human Rights), khususnya pasal 3, 5, dan 18. Dimana pasal 3 berbunyi : Everyone has the right to life, liberty and security of person. Kemudian pasal 5 yang berbunyi : No one shall be subjected to torture or to cruel, inhuman or degrading treatment or punishment. Dan berikutnya adalah pasal 18 yang berbunyi : Everyone has the right to freedom of thought, conscience and religion; this right includes freedom to change his religion or belief, and freedom, either alone or in community with others and in public or private, to manifest his religion or belief in

teaching, practice, worship and observance (United Nations, 1948).

Dari pasal-pasal tersebut yang tercantum dalam (Universal Declaration of Human Rights) jelas menyebutkan bahwa adanya perlindungan terhadap manusia dari segala bentuk penganiayaan dan tindak kekerasan, jaminan untuk rasa aman, serta kebebasan beragama. Dan segala bentuk diskriminasi, penganiayaan, kekerasan, dan adanya ancaman sehingga etnis Rohingnya merasa tidak aman, yang terjadi di Myanmar seperti yang sudah dijelaskan sebelumnya mencerminkan bahwa terjadi pelanggaran HAM di negara tersebut. Dan perlu kita ingat bahwa deklarasi universal tentang HAM ini secara eksplisit diadopsi untuk tujuan mendefinisikan arti dari kata-kata "kebebasan fundamental" dan "hak asasi manusia" yang muncul di Piagam PBB, yang bersifat mengikat semua negara anggota. Untuk alasan ini, Deklarasi Universal adalah dokumen konstitutif fundamental PBB. Selain itu, banyak pengacara internasional percaya bahwa Deklarasi tersebut merupakan bagian dari hukum kebiasaan internasional, dan merupakan alat yang ampuh dalam menerapkan tekanan diplomatik dan moral untuk pemerintah yang melanggar isi dari artikel deklarasi tersebut. Pada tahun 1968, dalam Konferensi Internasional tentang Hak Asasi Manusia, PBB menyarankan bahwa Deklarasi tersebut "merupakan kewajiban bagi anggota masyarakat internasional", dan berlaku untuk semua orang. Maka dari itu berarti Myanmar telah melanggar deklarasi universal tentang HAM yang seharusnya berlaku untuk seluruh komunitas internasional tersebut tanpa terkecuali (Kusuma, 2015). 
b. Diplomasi Kemanusiaan Yang Dilakuakan

Pemerintah

\section{Indonesia}

Konflik yang terjadi secara beruntun pada tahun 2012, 2013, 2015 dan 2017, telah mengakibatkan banyak korban jiwa di pihak etnis Rohingya. Bagi mereka yang lolos dari kematian, memilih untuk melarikan diri guna mencari suaka dan menjadi pengungsi di negara-negara tetangga Myanmar, diantaranya: Bangladesh, Thailand, Malaysia, dan Indonesia. Munculnya para pengungsi dari Myanmar ini cukup menjadi masalah dan memunculkan isu dalam level nasional bahkan internasional. Di Indonesia sendiri isu terkait datangnya para pengungsi etnis Rohingnya ini menjadi fenomena yang menarik perhatian. Pemerintah Indonesia dalam kasus ini sempat mengalami dilema dalam menentukan sikap antara memutuskan untuk menerima para pengungsi dan memberikan bantuan kepada mereka ataukah melarang para pengungsi Rohingnya itu untuk memasuki wilayah Indonesia.

Hal ini terlihat jelas dengan adanya perbedaan sikap dan tanggapan yang dilakukan oleh masyarakat dan pemerintah. Disatu pihak masyarakat, dalam hal ini yang dimotori oleh masyarakat Aceh yang pada tanggal 10 Mei 2015 memberikan pertolongan kepada para pengungsi yang terapung di lautan dengan kondisi yang memprihatinkan. Kapal yang membawa 582 imigran, ditemukan terdampar di perairan utara Aceh, yang kemudian di selamatkan oleh para nelayan di Aceh. Tindakan para nelayan Aceh tersebut mendapatkan dukungan dari mayoritas rakyat Indonesia. Namun ternyata pemerintah dalam hal ini TNI memiliki pendapat yang berlawanan. Dengan jelas petinggi dari TNI dalam hal ini Panglima TNI Jendral Moeldoko yang mengatakan bahwa: "Untuk suku Rohingya, sepanjang dia melintas Selat Malaka, kalau dia ada kesulitan di laut, maka wajib dibantu. Kalau ada sulit air atau makanan kami bantu, karena ini terkait human. Tapi kalau mereka masuki wilayah kita, maka tugas TNI untuk menjaga kedaulatan" (Asril, 2015). sikap pemerintah ini bukan tanpa alasan. Selain sikap TNI yang ingin menjaga kedaulatan wilayah, tapi juga dikarenakan Indonesia merasa tidak memiliki kewajiban menampung para pengungsi, karena Indonesia bukan termasuk negara yang meratifikasi konvensi mengenai Status Pengungsi 1951.

Namun demikian, dengan alasan kemanusiaan mayoritas masyarakat berpendapat bahwa bangsa Indonesia harus memberikan bantuan dan memperbolehkan 
para pengungsi ini untuk memasuki wilayah Indonesia dan memberikan mereka pertolongan dan tempat tinggal yang layak. Disisi lain pemerintah pada saat itu melalui TNI bersikeras untuk menjaga kedaulatan bangsa dengan mengamankan perbatasan dan melarang siapapun dari pihak luar untuk memasuki wilayah Indonesia termasuk para pengungsi etnis Rohingnya dari Myanmar. sikap pemerintah Indonesia ini cukup menimbulkan perdebatan dikalangan masyarakat. Mayoritas dari masyarakat indonesia dan juga dunia internasional manyayangkan sikap yang diambil pemerintah Indonesia yang pada awalnya tidak mengizinkan para pengungsi Rohingnya untuk memasuki wilayah Indonesia.

Namun kemudian setelah mengadakan pertemuan dengan negara lain yang menjadi tempat persinggahan para pengungsi Rohingnya yaitu Malaysia dan Thailand, Indonesia bersama dengan kedua negara tersebut akhirnya bersedia menerima dan menampung para pengungsi Rohingnya tersebut. Akhirnya dengan beberapa prasyarat yang ditetapkan oleh pemerintah Indonesia, para pengungsi Rohingnya bisa tinggal untuk sementara di camp-camp yang disediakan oleh pemerintah Indonesia dalam jangka waktu satu tahun. Kemudian setelah satu tahun maka mereka akan dipulangkan jika situasi memungkinkan atau akan dicarikan negara ketiga sebagai negara yang akan memberikan suaka kepada para pengungsi Rohingnya. penanganan terhadap para pengungsi Rohingnya di Indonesia dibantu oleh United Nations High Commissioner For Refugees (UNHCR).

Isu pelanggaran HAM yang dialami etnis Rohingya di Myanmar, menjadi isu nasional di Indonesia. Masyarakat Indonesia yang mayoritas beragama Islam banyak melakukan aksi damai untuk memberikan dukungan kepada etnis Rohingya dan menuntut pemerintah Myanmar untuk menghentikan seala bentuk tindakan yang merenggut hak-hak etnis Rohingya. Masyarakat juga menuntut pemerintah Indonesia untuk turut aktif mencari solusi terbaik untuk menyelesaikan kasus tersebut. Dengan menggunakan alasan kemanusiaan, pemerintah Indonesia mencoba untuk melakukan pendekatan kepada pemerintah Myanmar untuk mencari solusi guna meangani krisis kemanusiaan etnis Rohingya. Pemerintah Indonesia kemudian menawarkan solusi berupa formula $4+1$ terkait krisis kemanusiaan yang terjadi di Rakhine. Formula tersebut terdiri dari empat poin utama yaitu: mengembalikan stabilitas dan keamanan; (2) menahan diri secara maksimal dan 
tidak menggunakan kekerasan;

perlindungan kepada semua orang yang berada di Rakhine tanpa memandang suku dan agama; dan (4) pentingnya segera dibuka akses untuk bantuan kemanusiaan. Empat poin utama tersebut ditambah dengan satu poin tambahan yaitu implementasi dari rekomendasi Laporan Komisi Penasehat untuk Rakhine yang dipimpin oleh Kofi Annan yang harus dilakukan sesegera mungkin (Pujayanti, 2017).

Upaya diplomasi kemanusiaan yang dilakukan oleh pemerintah Indonesia dalam rangka penyelesaian masalah krisis kemanusiaan yang dialami etnis Rohingya di Myanmar, tidak berjalan dengan mulus. Ada beberapa hambatan yang dialami. Hambatan tersebut muncul dari komitmen Indonesia dan Myanmar yang memiliki aturan-aturan dalam mekanisme hubungan diplomatik dalam kerangka organisasi ASEAN.

Sebagai negara yang sama-sama menjadi bagian dari negara ASEAN, Indonesia dan Myanmar tentunya memiliki mekanisme tersendiri dalam melakukan hubungan diplomatik, yang tidak terlepas dari prinsip-prinsip yang telah disepakati dalam komunitas negara ASEAN. Dalam kasus penyelesaian krisis kemanusiaan yang dialami etnis Rohingya di Myanmar, pemerintah Indonesia tidak bisa masuk terlalu jauh untuk melakukan intervensi, karena terbentur dengan kedaulatan negara Myanmar itu sendiri. Dalam kesepakatan negara-negara ASEAN dikenal yang namanya prinsip fundamental yaitu “ASEAN Way”. Prinsip ini berisi terkait ketentuan bahwa negara-negara anggota ASEAN harus menghormati kedaulatan dan tidak mencampuri urusan dalam negeri negara-negara anggota ASEAN yang lain (Bangun, 2017). Dengan adanya " $A S E A N$ Way" tersebut, maka Indonesia tidak bisa langsusng masuk untuk menekan pemerintah Myanmar dalam penyelesaian krisis kemanusiaan etnis Rohinya.

Selain “ASEAN Way”, hambatan juga muncul dari sikap Myanmar yang tidak mau diintervensi dan cenderung menutup diri jika ada pihak dari negara lain yang ingin memberikan bantuan kemanusiaan kepada etnis Rohingya. Pemerintah Myanmar menetapkan aturan bahwa penyaluran bantuan terhadap etnis Rohingnya hanya boleh dilakukan jika mendapatkan izin dari pemerintah Myanmar. Bahkan, ketika PBB ingin menyalurkan bantuan kemanusiaan, semua bantuan tersebut ditolak oleh pemerintah Myanmar dengan alasan keamanan yang belum stabil (V. Maulana, 2017b). Kemudian Indonesia melakukan diplomasi dengan pemerintah Myanmar yang akhirnya kedua belah pihak bersepakat 
bahwa pemerintah Indonesia diperbolehkan

untuk memberikan bantuan kemanusiaan dengan syarat harus bekerja sama dengan lembaga kemasyarakatan yang ada di Myanmar. Dengan alasan tersebut akhirnya Indonesia membentuk Aliansi Kemanusian Indonesia untuk Myanmar (AKIM) (V. Maulana, 2017a), yang terdiri dari 11 LSM yang bergerak di bidang kemanusiaan yang diberikan mandat untuk memberikan dan menyalurkan bantuan dengan menjalin kerjasama dengan LSM yang ada di Myanmar (Taufiqqurahman, 2017). Adapun 11 lembaga kemanusiaan asal Indonesia yang tergabung dalam AKIM dapat dilihat dalam tabel berikut ini:

Tabel 1. Daftar 11 Lembaga Kemanusiaan yang tergabung dalam AKIM

\begin{tabular}{|l|l|}
\hline No & \multicolumn{1}{|c|}{ Nama Lembaga } \\
\hline 1. & $\begin{array}{l}\text { Muhammadiyah D Disaster } \\
\text { Management Centre }\end{array}$ \\
\hline 2. & $\begin{array}{l}\text { Lembaga Penanggulangan } \\
\text { Bencana dan Perubahan Iklim - } \\
\text { Nahdlatul Ulama }\end{array}$ \\
\hline 3. & PKPU Human Initiative \\
\hline 4. & Dompet Dhuafa \\
\hline 5. & Rumah Zakat \\
\hline 6. & $\begin{array}{l}\text { Dompet Peduli Ummat - Daarut } \\
\text { Tauhiid }\end{array}$ \\
\hline 7. & LAZIS Wahdah \\
\hline
\end{tabular}

\begin{tabular}{|l|l|}
\hline 8. & $\begin{array}{l}\text { Laznas Lembaga Manajemen } \\
\text { Infaq (LMI) }\end{array}$ \\
\hline 9. & Aksi Cepat Tanggap \\
\hline 10. & $\begin{array}{l}\text { Lazis Dewan Da'wah Islamiyah } \\
\text { Indonesia }\end{array}$ \\
\hline 11. & Social Trust Fund - UIN Jakarta \\
\hline \multicolumn{2}{|l}{ Sumber: }
\end{tabular}

https://www.dompetdhuafa.org/post/detail/8241/releasepenanganan-konflik-kemanusiaan-rohingya-dan-rakhinedi-myanmar

Melalui AKIM, pemerintah Indonesia akhirnya dapat memberikan bantuan kemanusiaan terhadap etnis Rohingya di Myanmar, dimana sebeumnya segala bentuk bantuan kemanusiaan telah mendapatkan blokade dari pemerintah Myanmar. Strategi yang digunakan pemerintah Indonesia untuk bisa memberikan bantuan kepada korban kekerasan di Rakhine State, Myanmar, merupakan bentuk aplikatif dari rekomendasi yang dikeluarkan oleh Advisory Commission on Rakhine State yang dipimpin oleh Kofi Annan, yang menyatakan bahwa model bantuan Internasional terhadap isu-isu kemanusiaan harus bersifat partisipatif dan inklusif (Kementerian Luar Negeri Republik Indonesia, 2017), (rakhine commission, 2017). Strategi untuk berkolaborasi dengan beberapa LSM di Indonesia dipilih oleh pemerintah Indonesia dalam rangka membentuk suatu model bantuan yang bersifat partisipatif dan inklusif dengan tujuan untuk semakin 
membangun kesadaran masyarakat tentang konsep Human Security.

Selain itu inisiasi dari pemerintah untuk membentuk AKIM karena adanya blokade dari pemerintah Myanmar yang menghambat niat pemerintah Indonesia untuk memberikan bantuan terhadap etnis Rohingnya. Pemerintah Myanmar menetapkan aturan bahwa penyaluran bantuan terhadap etnis Rohingnya hanya boleh dilakukan jika mendapatkan izin dari pemerintah Myanmar. Pada kenyataannya ketika PBB ingin menyalurkan bantuan kemanusiaan, semua bantuan tersebut ditolak oleh pemerintah Myanmar dengan alasan keamanan yang belum stabil. Untuk itulah kemudian Indonesia melakukan pendekatan diplomasi dengan pemerintah Myanmar yang akhirnya kedua belah pihak bersepakat bahwa pemerintah Indonesia diperbolehkan untuk memberikan bantuan kemanusiaan dengan syarat harus bekerja sama dengan lembaga kemasyarakatan yang ada di Myanmar. Dengan alasan tersebut akhirnya Indonesia membentuk Aliansi Kemanusian Indonesia untuk Myanmar (AKIM) dengan melibatkan LSM kemanusiaan dari Indonesia untuk mempermudah menjalin kerjasama dengan LSM yang ada di Myanmar (Taufiqqurahman, 2017), (V. Maulana, 2017b).

\section{Pada}

2019

pemerintah

Indonesia menyadari benar bahwa konflik yang terjadi antara etnis Rohingnya dengan penduduk di Rakhine State yang kemudian melibatkan pihak pemerintah Myanmar merupakan masalah internal negara Myanmar. Pemerintah Indonesia tidak mimiliki hak untuk mencampuri urusan dalam negeri Myanmar yang mrupakan negara yang berdaulat. Namun demikian, wakil presiden Indonesia Jusuf Kalla menyatakan bahwa berhubung negara Indonesia merupakan sebuah negara yang meyoritas penduduknya memeluk agama Islam maka negara Indonesia harus memberikan bantuan kepada etnis Rohingnya yang menjadi korban konflik yang terjadi di Myanmar. Disamping ini adalah masalah kemanusiaan, ada beban moral untuk membantu etnis Rohingnya (Purnomo, 2016).

\section{Kesimpulan}

Etnis Rohingya di Myanmar telah mengalami diskriminasi dan perampasan hak-hak yang dimiliki. Mengalami tindakan kekerasan, dirampas kewarganegaraannya, bahkan banyak yang meninggal dunia dari rentetan konflik yang terjadi, bahkan mereka harus mengungsi ke berbagai negara untuk menyelamatkan diri. Isu pelanggaran HAM yang dialami oleh etnis Rohingya 
telah menjadi perhatan komunitas internasioal. Indonesia sebagai salah satu negara yang menjadi tujuan para pengungsi asal Myanmar berkomitmen untuk aktif mencari solusi terbaik dan menghentikan pelanggaran HAM yang dialami oleh para etnis Rohingya. Dengan alasan kemanusiaan, pemerintah Indonesia telah melakukan langkah-langkah untuk memberikan bantuan kepada para korban baik yang menjadi pengungsi di Indonesia, ataupun mereka yang masih berada di Rakhine dan terancam keselmatannya.

Pemerintah Indonesia telah menggunakan apa yang disebut dengan diplomasi kemanusiaan, yaitu sebuah pendekatan dilomasi untuk kepentingan kemanusiaan dan bukan kepentingan yang bersifat material. Adapun strategi yang dilakukan oleh pemerintah Indonesia diantaranya: melakukan pendekatan diplomasi antar pemerintah Indonesia dengan pemerintah Myanmar (dengan tetap memperhatikan ASEAN Way), berkolaborasi dengan PBB sebagai struktur internasional (menawarkan formula $4+1$ sebagai bentuk implementasi dari rekomendasi Laporan Komisi Penasehat untuk Rakhine yang dipimpin oleh Kofi Annan), melibatkan pihak sipil untuk menyalurkan bantuan kepada etnis Rohingya di Myanmar (membentuk AKIM yang terdiri dari 11 lembaga kemanusiaan). Strategi-strategi diplomasi kemanusiaan tersebut terbukti dapat menembus blokade yang dilakukan oleh pemerintah Myanmar untuk menghalangi dunia internasional memberikan bantuan kepada etnis Rohingya.

\section{Referensi}

Asril, S. (2015, May 12). Panglima TNI Tolak Kapal Pengungsi Rohingya Masuk RI, tapi Bersedia Beri Bantuan. Kompas.com. Retrieved from

https://nasional.kompas.com/read/201 5/05/15/20213301/Panglima.TNI.Tol ak.Kapal.Pengungsi.Rohingya.Masuk .RI.tapi.Bersedia.Beri.Bantuan

Bangun, B. H. (2017). Tantangan ASEAN dalam Melakukan Penanganan Pengungsi Rohingya. Ilmu Hukum, 4(3), 569-587.

BBC Indonesia. (2017, September 5). Konflik Myanmar: Pengungsi Rohingya membanjiri Bangladesh. BBC.COM.

Bonasir, R. (2017). Menengok fakta-fakta di wilayah konflik Rakhine, Myanmar. BBC INDONESIA. Retrieved from https://www.bbc.com/indonesia/dunia $-40676548$

Kementerian Luar Negeri Republik Indonesia. (2017). Komitmen Bantu 
Myanmar, Menlu Luncurkan Program

Bantuan Kemanusiaan. Retrieved April 16, 2018, from https://www.kemlu.go.id/id/berita/ber ita-perwakilan/Pages/Komitmen-

Bantu-Myanmar,-Menlu-Luncurkan-

Program-Bantuan-Kemanusiaan.aspx

Kusuma, A. J. (2015). The Issue of Human

Rights Violation Towards Rohingnya

Ethnic Group and the Role of International Community. In The Golden Triangle (Indonesia-IndiaTiongkok) Inter relations in Religion,

Science, Culture, and Economic (Vol. 12, pp. 16-23). Semarang: Wahid Hasyim University. Retrieved from https://publikasiilmiah.unwahas.ac.id/ index.php/ISC/article/view/1268

Mangku, D. G. S. (2013a). KASUS

PELANGGARAN HAM ETNIS ROHINGYA : DALAM PERSPEKTIF ASEAN. Media Komunikasi FIS, 12(2), 60-69.

Mangku, D. G. S. (2013b). Kasus Pelanggaran HAM Etnis Rohingya: dalam Perspektif ASEAN. Media Komunikasi FIS, 12(2), 60-69. Retrieved from https://ejournal.undiksha.ac.id/index. php/MKFIS/article/view/1708/1495

Maulana, A. (2018). Menlu Retno Marsudi: Indonesia Mengedepankan Diplomasi Perdamaian dan
Kemanusiaan. Retrieved July 3, 2019, from

http://www.unpad.ac.id/2018/12/menl u-retno-marsudi-indonesiamengedepankan-diplomasiperdamaian-dan-kemanusiaan/

Maulana, V. (2017a, August). Menlu Retno Luncurkan Aliansi Kemanusiaan Indonesia. SINDONEWS.COM. Retrieved from https://international.sindonews.com/r ead/1235597/40/menlu-retnoluncurkan-aliansi-kemanusiaanindonesia-untuk-myanmar1504167196

Maulana, V. (2017b, September 4). Myanmar Tolak Bantuan PBB untuk Rakhine. SINDONEWS.COM. Retrieved from https://international.sindonews.com/r ead/1236576/40/myanmar-tolakbantuan-pbb-untuk-rakhine1504526620

Minear, L., \& Smith, H. (2007). Humanitarian Diplomacy: Practitioners and Their Craft. New York: United Nations University Press.

Mitzy, G. I. (2014). Perlawanan Etnis Muslim Rohingya terhadap Kebijakan Diskriminatif Pemerintah BurmaMyanmar. Indonesian Journal of International Studies (IJIS), I(2), 
153-164.

Retrieved

from

http://www.indies.myphp.net/index.p

hp?option=com

content $\&$ view $=$ article \&id=103:tentan

grohingya \&catid=13: catatan-minggu-

ini\&Itemid $=54$

Moy, L. Y., \& Kusuma, A. J. (2016). Latar

Belakang Indonesia Menerima

Pengungsi Rohingya Pada Tahun

2015 (Analisa Konstruktivis). Jurnal

Global Insight, 1(1).

Muhaimin. (2017, September 1). Korban

Tewas Konflik Berdarah di Rakhine Hampir $\quad 400 \quad$ Orang.

SINDONEWS.COM. Retrieved from

https://international.sindonews.com/r

ead/1235831/40/korban-tewas-

konflik-berdarah-di-rakhine-hampir-

400-orang-1504249040

Nadlir, M. (2017, September 3). Bantuan dan Pertolongan Indonesia untuk Etnis Rohingya di Myanmar. Kompas.com. Retrieved from https://regional.kompas.com/read/201 7/09/03/16003361/bantuan-danpertolongan-indonesia-untuk-etnisrohingya-di-myanmar

Our world in Data. (2017). Refugee population by country or territory of origin. Retrieved July 29, 2019, from https://ourworldindata.org/grapher/ref ugee-population-by-country-orterritory-of- origin?tab $=$ chart\&time $=1990 . .2017 \&$ country=MMR

PAHAM INDONESIA. (2012). ROHINGYA 101 DATA DAN FAKTA (TENTANG ROHINGYA, ARAKAN $D A N$ RAKHINE ). jakarta. Retrieved from

https://indonesia4rohingyadotorg.files .wordpress.com/2012/08/rohingya101-data-dan-fakta.pdf

Pujayanti, A. (2017). Indonesia dan Tragedi Kemanusiaan Rohingya. Majalah Info Singkat Hubungan Internasional, IX(17), 5-8. Retrieved from

http://berkas.dpr.go.id/puslit/files/info _singkat/Info Singkat-IX-17-I-P3DISeptember-2017-179.pdf

Purnomo, N. R. (2016, December 13). Jusuf Kalla Jelaskan Alasan Pemerintah RI Harus Bantu Selesaikan Konflik Rohingya Tribunnews. Tribunnews.com. Retrieved from http://www.tribunnews.com/nasional/ 2016/12/13/jusuf-kalla-jelaskanalasan-pemerintah-ri-harus-bantuselesaikan-konflik-rohingya

Purwanto, A. (2015). Menelisik Akar Persoalan Rohingya. Kompas.com. Retrieved from http://print.kompas.com/baca/2015/06 /03/Menelisik-Akar-Persoalan- 
rakhine commission. (2017). Towards a peaceful, fair and prosperous future for the people of rakhine. Retrieved April 16, 2018, from http://www.rakhinecommission.org/ Roy, S. L. (1991). Diplomasi. (Herwanto \& Mirsawati, Eds.) (1st ed.). jakarta: CV. Rajawali.

Taufiqqurahman, M. (2017, September 19). Kecuali dari Indonesia, Myanmar Tolak Bantuan untuk Etnis Rohingnya. detikNews. Retrieved from https://news.detik.com/berita/d3649373/kecuali-dari-indonesiamyanmar-tolak-bantuan-untuk-etnisrohingnya

Tempo.co. (2015). Pengungsi Rohingya Berkukuh Mau ke Australia. Tempo.co. Retrieved from https://nasional.tempo.co/read/66945 8/pengungsi-rohingya-berkukuh-mauke-australia/full\&view $=$ ok

United Nations. (1948). The Universal Declaration of Human Rights. Retrieved July 8, 2019, from https://www.un.org/en/universaldeclaration-human-rights/

Yudyachandra, A. D. (2015). Rohingya,

Antara Solidaritas ASEAN dan Kemanusiaan. Masyarakat ASEAN, 9-11. Retrieved from https://ex.kemlu.go.id/Majalah/ASEA 